14

\title{
Нанокластеры гидроксиапатита в субэндотелиальных структурах полулуний аорты у пациентов с кальцинированным аортальным стенозом
}

\author{
(C) С.Г. Ястребов ${ }^{1}$, Н.И. Гуляев ${ }^{2}$, А.С. Галенко ${ }^{2}$, М. Прус ${ }^{3}$, А.В. Сиклицкая ${ }^{3}$ \\ ${ }^{1}$ Физико-технический институт им. А.Ф. Иофрфе РАН, Санкт-Петербург, Россия \\ ${ }^{2}$ Военно-медицинская академия им. С.М. Кирова, Санкт-Петербург, Россия \\ ${ }^{3}$ Institute of Physical Chemistry, Polish Academy of Sciences, Warsaw, Poland \\ E-mail: Yastrebov@mail.ioffe.ru
}

Поступило в Редакцию 16 ноября 2018 г.

В окончательной редакции 22 ноября 2018 г.

Принято к публикации 22 ноября 2018 г.

\begin{abstract}
Приведены результаты исследования картины рентгеновской дифракции кальцинатов, выделенных из аортальных полулуний пациентов с кальцинированным аортальным стенозом. Показано, что картина дифракции формируется сферическими образованиями гексагонального гидроксиапатита, диаметры которых распределены по логарифмически нормальному закону. Построена модель структуры таких образований, обсуждаются механизмы их зарождения, закрепления частиц (инкапсуляции) гидроксиапатита в ограниченном поровом пространстве базальной мембраны полулуний аорты.
\end{abstract}

DOI: 10.21883/PJTF.2019.04.47338.17595

В настоящее время заболевания сердечно-сосудистой системы остаются основной причиной смерти в промышленно-развитых странах, в том числе в России. Ишемическая болезнь сердца и артериальная гипертензия занимают лидирующие позиции в списке нозологических единиц, вызывающих наибольшее количество летальных исходов, а сразу вслед за ними располагается кальцинированный аортальный стеноз - патология лиц пожилого и старческого возраста, которая год от года ставится все более актуальной вследствие повсеместного увеличения средней продолжительности жизни. Морфологически кальцинированный аортальный стеноз характеризуется отложением кристаллов гидроксиапатита в створках полулунных клапанов аорты, что приводит к необратимому нарушению их структуры и функции. При этом в настоящее время не существует эффективных средств первичной или вторичной профилактики данного приобретенного порока. С целью поиска путей профилактики и лечения кальцинированного аортального стеноза представляется необходимым исследование механизмов образования отложений гидроксиапатита на самых ранних стадиях его роста, когда размеры частиц гидроксиапатита не превышают нескольких десятков нанометров [1].

В настоящей работе исследована картина рентгеновской дифракции порошков биологического гидроксиапатита методом, описанным в работе [2], и проведено сравнение размеров кристаллов с размерами пор базальной мембраны.

Аортальные полулуния у пациентов с кальцинированным аортальным стенозом забирали при оперативном вмешательстве (протезировании клапана). Из кальцинированных полулуний стерильным скальпелем механи- чески вынимались кальцинаты, которые затем тщательно собирались и высушивались. В дальнейшем неорганическая минеральная часть образца отделялась от органической матрицы, состоящей из коллагеновых волокон по методике [3]. Методами порошковой рентгенографии определялся фазовый состав биогенных агрегатов и синтезированных осадков. Съемка образцов осуществлялась с использованием рентгеновского порошкового дифрактометра Rigaku MiniFlex II с медным катодом. Степень кальцинации оценивалась по Агатсону [4]. Вычисление индекса Агатсона проводилось с помощью анализа компьютерной томограммы аортального клапана. Для этого на изображении аортального клапана на компьютерной томограмме выделялись области кальцинирования, т.е. области с высоким ослаблением рентгеновского излучения. Взвешенная по поверхности плотность для области, занимаемой кальцинатами, измеряемая в единицах Хаунсфилда [4], умножается на общую площадь кальцинатов. В работе приведена типичная для всех исследованных отложений кривая рентгеновской дифракции образцов кальцинатов пациента средней тяжести (индекс Агатсона 143).

Известно, что с помощью метода рентгенофазового анализа помимо установления природы вещества по идентификации уникальной картины дифракции (интенсивность и положение пиков на дифрактограмме) обычно определяют также размер средневзвешенных по объему частиц методом Шеррера. Сравнительно недавно было показано, что кривые дифракции чувствительны к форме частиц и их распределению по размерам [2]. Так, в случае сферических наночастиц, диаметры которых подчиняются логарифмически нормальному закону распределения, форма кривой дифракции близка к ло- 
ренцевой [2]

$$
I(\theta)=\frac{2 A}{\pi} \frac{w}{4\left(\theta-\theta_{0}\right)^{2}+w^{2}} .
$$

Здесь $w$ - ширина контура на половине его высоты, $\theta-$ двойной угол рассеяния, $\theta_{0}-$ двойной угол Брэгга [2].

Типичная обзорная картина дифракции порошков полученных кальцинатов приведена на рис. 1. Сравнение со стандартом показывает, что во всех исследованных образцах присутствуют кристаллы гексагонального гидроксиапатита (JCPDS 9-432 [5]).

На рис. 2 показаны одиночный рефлекс дифрактограммы, представленной на рис. 1, в диапазоне углов $25-26^{\circ}$ и его аппроксимация выражением (1). Из рис. 2 видно, что функция Лоренца хорошо описывает зависимость интенсивности дифракции от ее двойного угла в исследуемой области. Значения подгоночных параметров приведены в подписи к рис. 2. Из близости к лоренцевой функции к экспериментальным данным следует, что в нашем случае форма нанокластеров гидроксиапатита близка к сферической, а диаметры нанокластеров распределены по логарифмически нормальному закону [2]. Размер диаметра Шеррера, соответствующий ширине контура, составляет величину порядка $30 \mathrm{~nm}$.

Интересно провести сравнение полученных данных с литературными данными. Так, например, наличие в базальной мембране аорты и аортальных полулуний пор, диаметры которых примерно равны $30 \mathrm{~nm}$, могло бы подтвердить предположение о зарождении и росте в них нанокристаллов гидроксиапатита. Однако в литературе

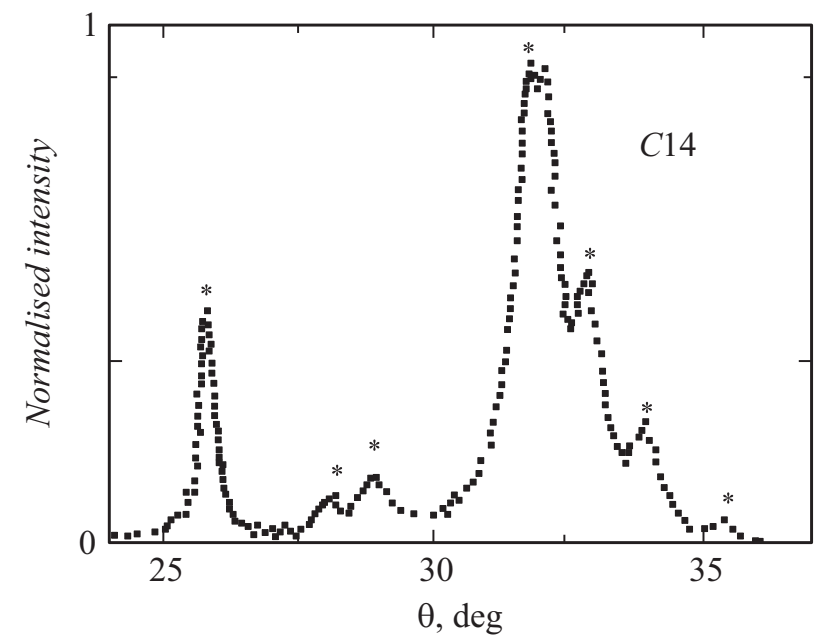

Рис. 1. Обзорная дифрактограмма кальцинатов, выделенных из кальцинированных аортальных полулуний пациента, страдающего аортальным стенозом средней тяжести (индекс Агатсона 143). В обозначении $C 14$ буква $C$ соответствует средней степени поражения аортального клапана, 14 - порядковый номер пациента. Звездочками помечены положения максимумов дифракции, соответствующие стандарту гексагонального гидроксиапатита, параметры решетки $a_{0}=9.44 \AA, c_{0}=6.88 \AA$ (JCPDS 9-432 [5]).

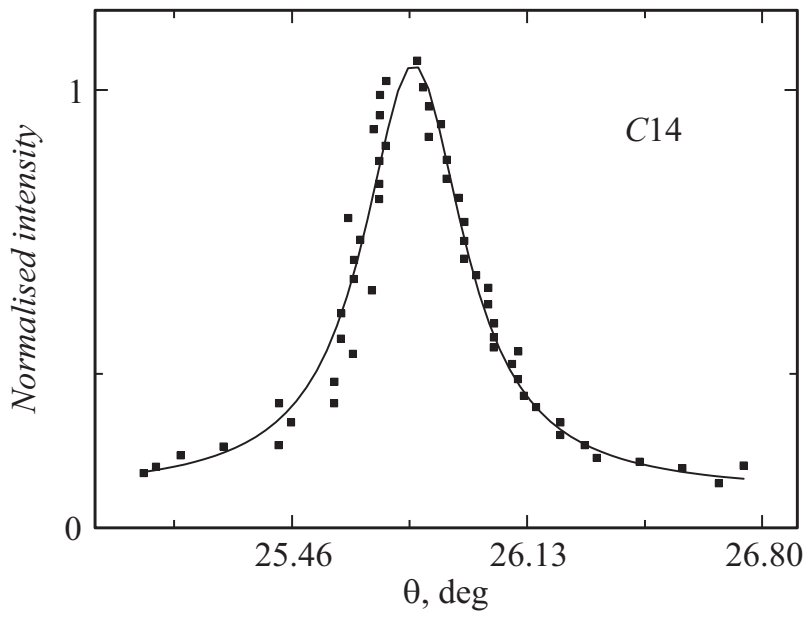

Рис. 2. Фрагмент дифрактограммы, показанной на рис. 1, в области отражения от плоскостей $\{002\}$. Точки - эксперимент, сплошная линия - аппроксимация лоренцианом (1). Параметры лоренциана: $\theta_{0}=25.81 \pm 0.004, w=0.348 \pm 0.028$; $\left(\chi^{2}=0.274, r^{2}=0.941\right)$.

практически отсутствуют данные по наноструктуре базальной мембраны аорты и аортальных полулуний человека. Поэтому мы сравнили наши данные по размерам кальцинатов с известными данными по диаметрам наноразмерных пор базальной мембраны свиньи. Известно, что свиньи являются хорошими модельными животными, позволяющими исследовать патологии человека. Как оказалось, диаметры пор базальной мембраны свиньи практически не отличаются от значения $30 \mathrm{~nm}$ [6]. Скорее всего, диаметры пор, как и диаметры заполняющих их нанокристаллов, распределены по логарифмически нормальному закону, как и размеры большинства подобных объектов, существующих в природе [7]. Факт близости размеров пор и нанокластеров подтверждает модель зарождения и роста нанокристаллов гидроксиапатита в порах базальной мембраны полулуний аорты у человека.

Остановимся на механизме зарождения нанокристаллов подробнее. Известно, что для нуклеации и роста кристаллов гидроксиапатита в организме человека необходимо концентрационное пересыщение плазмы крови по фосфору и кальцию. Из литературных источников известно также, что плазма крови пересыщена по отношению к гидроксиапатиту даже при физиологическом уровне кальция и фосфата в плазме крови $[8,9]$. Более того, в работе [9] сообщается о том, что нанометровые зародыши гидроксиапатита изначально присутствуют в плазме крови. В связи с указанным выше реалистичной представляется модель, рассматривающая зарождение кальцинатов (гидроксиапатита) в нанометровых порах базальной мембраны. В случае отслоения эндотелиального слоя от базальной мембраны эти поры заполняются плазмой крови. В плазме, как отмечалось выше, достигается концентрационное пересыщение прекурсорами 


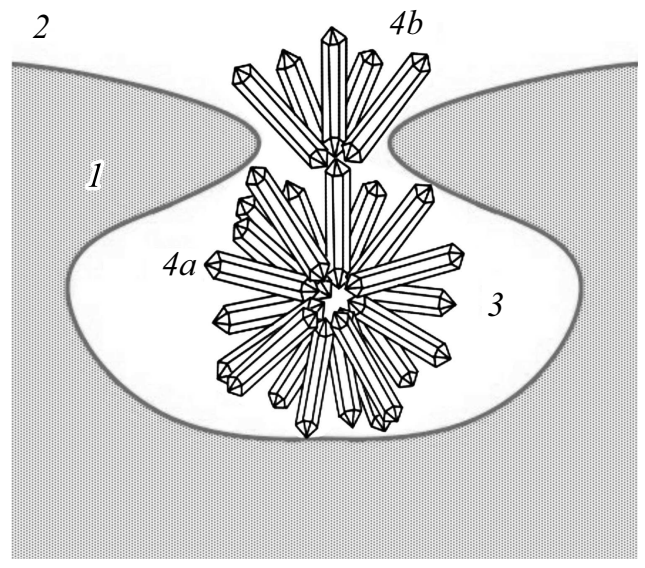

Pис. 3. Реконструкция нанокристалла гидроксиапатита, инкапсулированного в поре базальной мембраны аортального клапана. Схема поры базальной мембраны: 1 - тело базальной мембраны (коллаген), 2 - внешняя среда (кровь), 3 пора, заполненная плазмой крови, $4 a, 4 b-$ нанокристаллы гидроксиапатита. В центре пучка игольчатых образований гидроксиапатита находится зародыш.

гидроксиапатита, необходимое для зарождения и последующего роста нанокластеров гидроксиапатита в порах. При достижении границ поры растущим кристаллом происходит закрепление кристалла на ее границе, т.е. инкапсуляция в объеме поры. Изначально присутствующие в крови пациентов зародыши кальцинатов могут являться центрами кристаллизации нанокластеров гидроксиапатита.

В связи с изложенным выше можно предположить наличие единого механизма, провоцирующего зарождение и рост кальцинатов, а также инкапсуляцию в базальную мембрану. В основе этого механизма лежит нарушение функции эндотелия аортальных полулуний и самой аорты, т.е. в процессе жизнедеятельности организма зачастую по непонятным причинам происходит повреждение эндотелиальных клеток аорты и ее полулуний с их последующим отслоением и отшелушиванием током крови и заполнением пор субэндотелиальной базальной мембраны плазмой крови, содержащей зародыши кальцинатов. Учитывая особенности роста гидроксиапатита, исследованные в работе [10], можно предположить, что изучаемые нами сферические нанокристаллы похожи на ежей, иголки которых прижаты друг к другу, и представляют собой вытянутые кристаллики гидроксиапатита, как это показано на рис. 3. В центре „ежа“ находится зародыш, в роли которого, как известно, может выступать фрагмент решетки арагонита [10]. В случае дальнейшего увеличения размера нанокристалла в объеме поры может происходить его прорастание в соседние с порой области. В то же время верхняя его часть выходит из поры наружу и на нее также могут нарастать иголки гидроксиапатита, как показано на рис. 3.

Итак, выполненный анализ позволяет высказать предположение о том, что на начальных этапах патологии зарождение и рост кристаллов гидроксиапатита происходят в поровом пространстве субэндотелиального слоя базальной мембраны, что на ранних этапах развития патологии приводит к инкапсуляции нанокластеров кальцинатов в поры базальной мембраны.

Авторы благодарят ресурсный центр СПбГУ „Рентгенодифракционные методы исследования“ за измерения дифрактограмм, а также Г.В. Куранова за интерес к работе и А.А. Суворову за предоставленную информацию о структурных свойствах гидроксиапатита.

\section{Список литературы}

[1] Гуляев Н.И., Жуков М.В., Куранов Г.Л., Борисов Ю.А., Суглобова Е.Д., Ястребов С.Г., Пелешок А.С. // Ульяновск. мед.-биол. журн. 2017. № 1. С. 23-31.

[2] Ida T., Shimazaki S., Hibino H., Toraya H. // J. Appl. Cryst. 2003. V. 36. Pt 5. P. 1107-1115.

[3] $\mathrm{Li}$ R.C. Application of proteinases for DNA isolation of bone specimens. A Research report submitted to the U.S. Department of Justice. 2009. Document N 227502. 34 p.

[4] Hoffmann U., Brady T.J., Muller J. // Circulation. 2003. V. 108. V. 8. P. e50-e53.

[5] Sprio S. Bio-inspired regenerative medicine: materials, processes, and clinical applications. 1st ed. Pan Stanford, 2016. $412 \mathrm{p}$.

[6] Brody S., Anilkumar Th., Liliensiek S., Last J.A., Murphy Ch.J., Pandit A. // Tissue Eng. 2006. V. 12. N 2. P. 413-421.

[7] Limpert E., Stahel W.A., Abbt M. // BioSci. 2001. V. 51. N 5. P. 341-352.

[8] O’Neil W.C. // Kidney Int. 2007. V. 72. N 7. P. 792-796.

[9] Sohnel O., Grases F. // Urol. Res. 2011. V. 39. N 6. P. 429-436.

[10] Wang F., Guo Yu., Wang H., Yang L., Wang K., Ma X., Yao W., Zhang H. // Cryst. Eng. Comm. 2011. V. 13. N 19. P. 5634-5637. 